\title{
EFFECT OF INGESTION OF SOY YOGURT ON INTESTINAL PARAMETERS OF RATS FED ON A BEEF-BASED
}

ANIMAL DIET

\section{Raquel Bedani $^{1 *}$, Nadiége Dourado Pauly-Silveira ${ }^{1}$, Veridiana Soares Pereira Cano ${ }^{2}$, Sandro Roberto Valentini ${ }^{2}$, Graciela Font de Valdez ${ }^{3}$, Elizeu Antonio Rossi ${ }^{1}$}

${ }^{1}$ Departamento de Alimentos e Nutrição, Faculdade de Ciências Farmacêuticas, Universidade Estadual Paulista, Araraquara, SP, Brasil; ${ }^{2}$ Departamento de Ciências Biológicas, Faculdade de Ciências Farmacêuticas, Universidade Estadual Paulista, Araraquara, SP, Brasil; ${ }^{3}$ Centro de Referencia para Lactobacilos (CERELA), San Miguel de Tucumán, Argentina.

Submitted: September 10, 2010; Approved: May 16, 2011.

\begin{abstract}
The aim of this study was to investigate whether the ingestion of soy yogurt fermented with Enterococcus faecium CRL 183 would modify the intestinal count of enterococci, fecal $\mathrm{pH}$ and ammonia content in rats fed on a diet containing red meat. The rats were placed in 4 groups: for 60 days, group I was given a standard casein-based rodent feed and groups II-IV, the beef-based feed. From day 30, groups III-IV also received the following products: III) soy yogurt; IV) suspension of E. faecium CRL 183. At the start and on days 30 and 60, feces were collected for the determination of $\mathrm{pH}$, ammonia content, count of enterococci and identification of their species. On day 60, rats were sacrificed and their colons also removed for count of enterococci and identification of their species. Rats that ingested soy yogurt showed no significant change $(P<0.05)$ in fecal counts of Enterococcus spp., but, this rat group showed a higher count of E. faecium than rats that ingested suspension of E. faecium CRL 183. The ingestion of soy yogurt and E. faecium culture caused a significant rise $(P<0.05)$ in fecal $\mathrm{pH}$ and ammonia content. Our results suggest that consumption of soy yogurt fermented with E. faecium CRL 183 and L. helveticus subsp. jugurti could change the species of Enterococcus spp. present in the feces and colon of rats fed on a beef-based diet. However, the fermented soy product and the pure culture of E. faecium CRL 183 also induced undesirable effects such as the increase of fecal $\mathrm{pH}$ and ammonia content in the feces of rats fed on a beef-based diet.
\end{abstract}

Key words: Soy yogurt, Enterococcus faecium CRL 183, Fecal pH, Fecal ammonia content, Rats

\section{INTRODUCTION}

The intestinal microbiota plays an essential role in maintaining the health of the host. Many factors, such as the micro-environment, diet and $\mathrm{pH}$ of the intestinal medium affect the type of bacterial population found in the gastrointestinal tract and its metabolic activity $(11,13)$.

Research has indicated that the colonic microbiota is involved in the etiology of various diseases, for example, colon carcinogenesis, though no study has unequivocally defined the

\footnotetext{
*Corresponding Author. Mailing address: Universidade Estadual Paulista, Faculdade de Ciências Farmacêuticas, Departamento de Alimentos e Nutrição, Araraquara, SP, Brazil.; Tel.: +55-16-33016922 Fax: +55-16-33016920.; Email: raquelbedani@yahoo.com.br
} 
bacteria or the mechanisms involved in promoting the growth of colon tumors $(3,23)$. Many results suggest that the effect of diet on carcinogenesis could be mediated by changes in metabolic activity and composition of the colonic microbiota (12).

While the results of epidemiological studies have not been completely consistent, the consumption of red meat and animal fat in large amounts does appear to increase the risk of developing this cancer, in comparison with a vegetarian diet (16).

The high ingestion of red meat could increase the fecal content of ammonia, a compound considered a carcinogenesis promoter in rodent experimental models (37). Studies have pointed to a relationship between changes in intestinal microbiota and levels of fecal ammonia.

Some researchers have suggested that a high intestinal $\mathrm{pH}$ promotes colon cancer and that acidification of the colon contents may prevent the formation of carcinogens (8). According to Modler et al. (25), the lowering of the intestinal $\mathrm{pH}$ may influence colon cancer by preventing the growth of undesirable bacteria.

On the other hand, it has been revealed that the ingestion of products fermented with probiotic microorganisms can protect against intestinal carcinogenesis, as these bacteria can have beneficial effects on the composition of the microbiota and on the activity of enzymes that convert pro-carcinogens into carcinogens $(14,39)$. However, to profit from these effects, it is essential that the probiotics are present in larger numbers than the bacteria that cause undesirable bacteria (1).

Certain bacteria of the genus Enterococcus, such as E. faecium, are being used as probiotics in several countries (10, 26). Both the probiotic capacity of E. faecium and the functional properties of soy milk fermented with these lactic acid bacteria have stimulated the interest of a growing number of researchers.

In view of this, Rossi et al. (30) developed a yogurt-like fermented soy product (soy yogurt), using the lactic acid bacterial strains E. faecium CRL 183 (a strain isolated from
Tafí cheese, a homemade traditional cheese from the highlands in the province of Tucumán, Argentina) and Lactobacillus helveticus subsp. jugurti 416. This product had sensorial and technological properties similar to yogurts. Additionally, several beneficial effects were showed from the consumption of this product have been demonstrated in animals and humans, such as: reduction of serum cholesterol levels $(9,24,28,29$, 31); anticarcinogenic activity, especially in breast and colon cancer $(19,35)$; modulation of immune response (38) and positive effects on bone metabolism $(4,33)$.

Therefore, the present study was designed to investigate whether the consumption of soy yogurt fermented with $E$. faecium CRL 183 would modify the intestinal count of enterococci, fecal $\mathrm{pH}$ and ammonia content in rats fed on a diet containing red meat.

\section{MATERIALS AND METHODS}

\section{Experimental animals and diet}

Forty 8-week-old male SPF Wistar rats were obtained from the central animal facility (CEMIB) at the State University of Campinas (UNICAMP, Campinas, SP, Brazil). During the 60-day experimental period, the rats had free access to a formulated diet and water and were housed in ventilated stands (Alesco Indústria e Comércio Ltda, Brazil) with a controlled 12h: $12 \mathrm{~h}$ light/dark photoperiod, at $23 \pm 2{ }^{\circ} \mathrm{C}$. All procedures conformed to the recommendations of the Brazilian College of Animal Experimentation (COBEA) and had the approval of the Research Ethics Committee of the UNESP School of Pharmaceutical Sciences at Araraquara (resolution: 29/2005). After a week of acclimatization to experimental conditions, the rats were separated at random into 4 groups of 10 rats each, as detailed in the experimental plan outlined in Figure 1.

The duration of the experiment was 60 days and animal feces were collected at the start $\left(\mathrm{T}_{0}\right)$ and on day $30\left(\mathrm{~T}_{30}\right)$ and 60 $\left(\mathrm{T}_{60}\right)$. These samples were homogenized aseptically and the resulting suspensions used for bacterial analysis. 
The rodent diets were prepared as recommended by Reeves et al. (27) of the American Institute of Nutrition (AIN) and stored frozen $\left(-14^{\circ} \mathrm{C}\right)$ in polyethylene bags. Rats in group I were fed on a standard diet for the maintenance of rodents (AIN-93M-casein), while the others were given the standard diet modified in its source of protein and animal fat content, by replacing the casein with powdered beef (Table 1). For this meat-based diet, a lean cut of beef was chosen, minced and dehydrated in a drying oven, with air circulating at $105^{\circ} \mathrm{C}$, for 3-4h. The dried meat was then ground to a fine "flour", whose protein and lipid contents were determined by the Kjeldahl and Soxhlet methods (2), respectively.

At the end of 60 days, rats were sacrificed in a $\mathrm{CO}_{2}$ chamber and transferred to a laminar flow cabinet. The colon of each animal was removed aseptically to count and identify species of isolated colonies of enterococci.

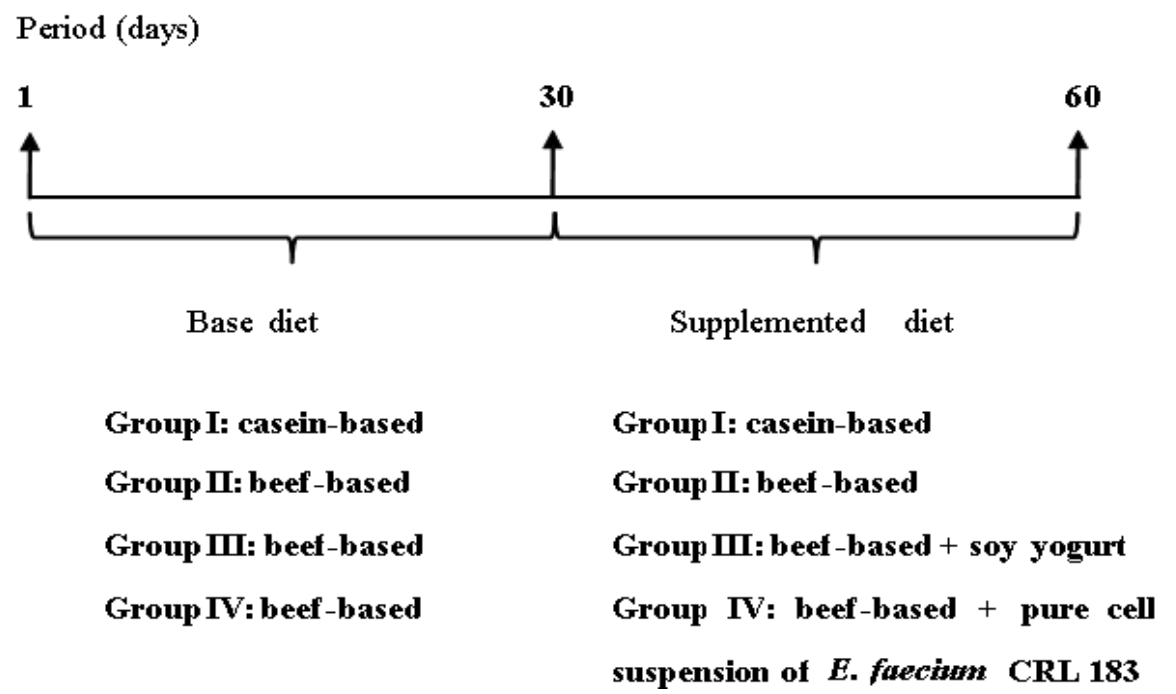

Figure 1. Phases of experimental procedure, according to group of rats.

Table 1. Composition of basic feed used throughout the 60-day experimental period.

\begin{tabular}{|c|c|c|}
\hline Ingredients (g/kg) & Standard rodent diet & Experimental diet \\
\hline Cornstarch & 465.69 & 441.25 \\
\hline Casein & 140.00 & \\
\hline Beef “flour” & ....... & 179.49 \\
\hline Dextrinized starch & 155.00 & 155.00 \\
\hline Sucrose & 100.00 & 100.00 \\
\hline Soybean oil & 40.00 & $\ldots \ldots$ \\
\hline Animal fat & ...... & 24.95 \\
\hline Cellulose & 50.00 & 50.00 \\
\hline Vitamins (AIN-93M-MX) & 35.00 & 35.00 \\
\hline Minerals (AIN-93-VX) & 10.00 & 10.00 \\
\hline L-cystine & 1.80 & 1.80 \\
\hline Choline bitartrate $(411 \mathrm{~g} / \mathrm{kg}$ of choline) & 2.50 & 2.50 \\
\hline BHT & 0.008 & 0.008 \\
\hline Total & 1000.00 & 1000.00 \\
\hline \multicolumn{3}{|c|}{$\begin{array}{l}\text { Cornstarch: donated by ADRAM S.A. Indústria e Comércio (ADRAM, São Paulo, Brazil); } \\
\text { Commercial casein (Synth, São Paulo, SP, Brazil), with } 860 \mathrm{~g} / \mathrm{kg} \text { of protein, was used as control protein source; } \\
\text { Sucrose (Synth, Diadema, SP, Brazil); } \\
\text { Soybean oil (Liza, Mairinque, SP, Brazil); } \\
\text { Dextrinized starch, cellulose, choline bitartrate, vitamins and minerals (Rhoster, Araçoiaba da Serra, SP, Brazil); } \\
\text { L-cystine (Synth, Diadema, SP, Brazil); } \\
\text { BHT (butyl hydroxytoluene) (Sigma Aldrich, Germany): synthetic antioxidant; } \\
\text { The beef flour contained } 780 \mathrm{~g} / \mathrm{kg} \text { of protein and } 139 \mathrm{~g} / \mathrm{kg} \text { of fat }\end{array}$} \\
\hline
\end{tabular}




\section{Production of soy yogurt}

The fermented product was prepared weekly from soy milk (manufactured at the Production and Development Unit for Soy Bean Derivatives - UNISOJA - installed at the School of Pharmaceutical Sciences, UNESP), using the method described by Rossi et al. (30). The conventional bacterial inoculum was replaced by $3 \%(\mathrm{v} / \mathrm{v})$ of a mixture of exponential phase cultures of E. faecium CRL 183 and Lactobacillus helveticus subsp. jugurti 416. The fermentation was continued at $37^{\circ} \mathrm{C}$ until the product reached $\mathrm{pH} 4.5$.

\section{Pure culture of Enterococcus faecium}

The culture of E. faecium CRL 183 was grown on weekly in Tryptic Soy Broth (Acumedia, Baltimore, MD, USA). Bacteria in the late-log growth phase were collected by centrifugation $\left(1173 \mathrm{xg}, 5 \mathrm{~min}, 4^{\circ} \mathrm{C}\right)$ and washed with sterile phosphate buffered peptone water $(\mathrm{pH}$ 7.0). The cells were maintained in a solution of sterile phosphate peptone water until the moment of administration.

\section{Administration of products to animals}

The soy yogurt and pure suspension of E. faecium CRL 183 were administered every day for 30 days by gavage, at a dose of $3 \mathrm{~mL} / \mathrm{kg}$ body weight/day.

The population of E. faecium in the soy yogurt and the pure culture and L. helveticus in the soy yogurt remained at approximately $9 \log \mathrm{cfu} / \mathrm{mL}$ for at least 21 days of storage $(4 \pm$ $\left.1^{\circ} \mathrm{C}\right)$. However, as these products were produced weekly, the rats received the soy yogurt or the pure culture after no more than 7 days of refrigerated storage.

\section{Counts of Enterococcus spp. and identification of the species}

The samples were taken at the beginning $\left(\mathrm{T}_{0}\right)$, day $30\left(\mathrm{~T}_{30}\right)$ and on the last day of the experiment $\left(\mathrm{T}_{60}\right)$ for feces and at $\mathrm{T}_{60}$ for colons.

One gram of animal feces was homogenized in $99 \mathrm{~mL}$ of sterile peptone water. After the sacrifice of animals at the end of the experimental period (day 60), the colons were removed and each was washed with sterile saline solution $(0.9 \%)$ to remove the feces from the tissue. Each colon was then homogenized in peptone water (1:9) in a blender (Nova Ética, Vargem Grande Paulista, SP, Brazil). The suspensions were diluted serially and appropriate dilutions were used to inoculate selective culture media. The analysis was carried out on triplicate.

KF Streptococcus agar (Acumedia, Baltimore, MD, USA) was used to count enterococci. The plates were incubated at $37^{\circ} \mathrm{C}$ for $48 \mathrm{~h}$. Colonies with distinct morphologies were picked out and transferred to Bile Esculin Azide Agar medium (Acumedia, Baltimore, MD, USA.) for confirmation of the Enterococcus genus. API 20 Strep (Biomérieux, Marcyl'Etoile, France) was used to identify the species of enterococci. Colonies identified as E. faecium were cultured on TSB medium (Acumedia, Baltimore, MD, USA.) for genomic DNA extraction.

\section{S rDNA amplification}

Species confirmation of E. faecium was performed by PCR amplification of genomic DNA, purified with the kit DNeasy (Qiagen, Valencia, CA, USA), from colonies isolated from rat feces at $\mathrm{T}_{0}, \mathrm{~T}_{30}$ and $\mathrm{T}_{60}$ of the experimental period and colons at $\mathrm{T}_{60}$. DNA fragments encoding the 16S-23S rRNA spacer region were amplified with the primer combination Ent1 (5'-ATTACGGAGACTACACACTTTG-3') and Ent2 (5'TAGCCATAGAAGTTACATCAAG-3') (Invitrogen, São Paulo, SP, Brazil), as previously described (20).

PCR reactions contained each oligonucleotide at $1 \mu \mathrm{M}$, each dNTP at $0.2 \mathrm{mM}, 100 \mathrm{ng}$ of genomic DNA, IX PCR buffer and 1.25 units of Taq DNA polymerase (Fermentas, Burlington, ON, Canada) in a total volume of $50 \mu \mathrm{L}$. Reactions were performed in $0.2 \mathrm{~mL}$ microcentrifuge tubes with the GeneAmp PCR System 9700 (Applied Biosystems, Carlsbad, CA, USA). PCR conditions were as follows: 30 cycles of denaturation at $95^{\circ} \mathrm{C}$ for $1 \mathrm{~min}$, primer annealing at $53^{\circ} \mathrm{C}$ for 1 min and elongation at $72^{\circ} \mathrm{C}$ for $1 \mathrm{~min}$. PCR products were separated by $1.0 \%$ agarose gel eletrophoresis in TAE buffer 
(40mM Tris, $0.11 \%$ glacial acetic acid and 1mM EDTA).

\section{Determination of $\mathrm{pH}$ and ammonia content}

For each experimental group, an aliquot of feces was diluted one-fold in distilled water, homogenized by vortexing and the $\mathrm{pH}$ was measured with a pHmeter (Qualxtron, Brazil) (36). The fecal ammonia concentration was determined in the same mixture, using an Orion 710A potentiometer (Thermo Fisher Inc, Beverley, MA, USA) with an Orion 95-12 ammonia-specific electrode (Thermo Fisher Inc, Beverley, MA, USA) (21).

\section{Statistical analysis}

Results were reported as mean \pm SEM. The data were tested by analysis of variance (ANOVA) and the means were compared across groups and experimental periods by the Tukey test, significance being declared when $P<0.05$. All analyses were carried out with the BIOSTAT statistical package.

\section{RESULTS AND DISCUSSION}

\section{Determination of $\mathrm{pH}$ and ammonia content}

According to results shown in Table 2, there was an increase of fecal pH during the 60-day of experimental period in all treatment groups except groups I and II, which showed slight falls at $\mathrm{T}_{60}$.

There were significant differences in fecal $\mathrm{pH}$ among the treatment groups at $\mathrm{T}_{0}$. After consumption of formulated feed $\left(\mathrm{T}_{30}\right)$, there was an increase of fecal $\mathrm{pH}$ in all experimental groups. However, the rats that received casein-based feed exhibited a lower $\mathrm{pH}$ than those receiving beef-based feed at $\mathrm{T}_{30}$ and $\mathrm{T}_{60}$. The administration of E. faecium CRL 183, incorporated in soy yogurt the pure culture suspension, did not cause any reduction in $\mathrm{pH}$. Nevertheless, by comparing groups III and IV, it can be seen that the fecal $\mathrm{pH}$ of animals that consumed soy yogurt (III) was lower at $\mathrm{T}_{60}$ than that of animals given the pure culture (IV).

Some researchers have suggested that colon cancer may be influenced beneficially by reducing the intestinal $\mathrm{pH}$, thereby preventing the growth of undesirable bacteria and the production of carcinogenic compounds $(6,25)$. In our study it was shown that the consumption of soy yogurt and a pure culture of E. faecium CRL 183 (a probiotic microorganism) $(30,31,35)$ did not reduce the rise of fecal $\mathrm{pH}$ caused by consumption of beef-based feed; on the contrary, the ingestion of these products led to a higher fecal $\mathrm{pH}$ at $\mathrm{T}_{60}$.

Table 2. Values of $\mathrm{pH}$ and ammonia content $(\mathrm{mg} / \mathrm{L})$ in feces of rats during experimental period.

\begin{tabular}{cccc}
\hline Group & $\mathbf{T}_{\mathbf{0}}$ & $\mathbf{T}_{\mathbf{3 0}}$ & $\mathbf{T}_{\mathbf{6 0}}$ \\
\hline & & $\mathbf{p H}$ & \\
I & $6.52 \pm 0.02^{\mathrm{aA}}$ & $7.28 \pm 0.03^{\mathrm{cB}}$ & $7.13 \pm 0.02^{\mathrm{bA}}$ \\
II & $6.93 \pm 0.03^{\mathrm{aD}}$ & $7.80 \pm 0.02^{\mathrm{cA}}$ & $7.51 \pm 0.04^{\mathrm{bB}}$ \\
III & $6.74 \pm 0.04^{\mathrm{aB}}$ & $7.82 \pm 0.03^{\mathrm{bA}}$ & $8.03 \pm 0.03^{\mathrm{cC}}$ \\
IV & $6.82 \pm 0.03^{\mathrm{aC}}$ & $7.83 \pm 0.02^{\mathrm{bA}}$ & $8.43 \pm 0.03^{\mathrm{cD}}$ \\
& & $\mathbf{A m m o n i a}(\mathbf{m g} / \mathbf{L})$ & \\
I & $105.33 \pm 1.53^{\mathrm{bD}}$ & $76.73 \pm 0.31^{\mathrm{aA}}$ & $150.43 \pm 0.51^{\mathrm{cA}}$ \\
II & $62.23 \pm 0.25^{\mathrm{aB}}$ & $175.93 \pm 0.90^{\mathrm{cC}}$ & $236.81 \pm 0.81^{\mathrm{bB}}$ \\
III & $56.60 \pm 0.40^{\mathrm{aA}}$ & $210.87 \pm 0.81^{\mathrm{bD}}$ & $260.90 \pm 0.85^{\mathrm{cC}}$ \\
IV & $85.47 \pm 0.50^{\mathrm{aC}}$ & $141.83 \pm 0.76^{\mathrm{bB}}$ &
\end{tabular}

Values (means \pm standard deviation) with different small letters on the same row, or with different capital letters in the same column, are significantly different $(P<0.05)$;

Rat group diets: $\mathrm{I}$ = casein-based feed alone; II = beef-based feed alone; III = beef-based feed supplemented after $\mathrm{T}_{30}$ with soy yoghurt; IV

$=$ beef-based feed supplemented after $\mathrm{T}_{30}$ with cell suspension from pure culture; $\mathrm{T}_{0}=$ start of standard (casein-based) and experimental

(beef-based) base diets; $\mathrm{T}_{30}=$ start of supplementation with products $\left(30\right.$ days); $\mathrm{T}_{60}=$ end of experiment $(60$ days $) ; \mathrm{n}=10$ 
Bouhnik et al. (7) evaluated the effects of prolonged ingestion of Bifidobacterium spp. fermented milk, with or without inulin, on fecal $\mathrm{pH}$ in healthy humans. The results showed that fecal $\mathrm{pH}$ did not vary throughout the three periods observed (basal, ingestion and post-ingestion periods).

On the other hand, Benno and Mitsuoka (6) found that subjects consuming B. longum for 5 weeks showed a reduction of fecal $\mathrm{pH}$ from the $3^{\text {rd }}$ to the final week of the tests.

In Table 2, we can also see that the fecal ammonia content increased in meat-based feed groups $\left(\mathrm{T}_{30}\right)$. After receiving soy yogurt and pure culture, the rats exhibited a further increase in the concentration of fecal ammonia at $\mathrm{T}_{60}$, which could explain the higher in fecal $\mathrm{pH}$ these groups. Comparing groups III and IV at $\mathrm{T}_{60}$, the lower concentration of fecal ammonia was found in the soy yogurt group.

While there were higher fecal $\mathrm{pH}$ and ammonia contents in groups III and IV, it is possible that the ingredients of soy yogurt and/or the presence of L. helveticus subsp. jugurti (or some metabolite produced during fermentation of soy yogurt) may have helped to reduce the rise of fecal $\mathrm{pH}$ and ammonia content in group III, when it is compared to group IV. A previous study showed that $L$. helveticus subsp. jugurti 416 has some characteristics of a probiotic strain (unpublished data). Nevertheless, other studies are required to confirm whether this strain can be considered a probiotic microorganism.

Ammonia is produced by a wide variety of intestinal bacteria, including enterobacteria, bacteroides and clostridia. This compound is considered a risk factor for colon cancer, owing to its capacity to promote alterations in cellular kinetics of the colon
(17).

Our results suggest that E. faecium CRL 183 may contribute to raising the fecal ammonia content and, thereby, increasing the fecal $\mathrm{pH}$, when the consumption of this microorganism is associated with a protein diet based on cooked meat. One of the enzymes responsible for ammonia production is urease (18). Simonová et al. (34) studied 29 strains of E. faecium and verified that all showed ureolytic activity.

It is probable that other factors are more decisive in preventing colon cancer, since Sivieri et al. (35) observed a lower incidence of tumors in animals that consumed a pure culture of $E$. faecium CRL 183.

\section{Counts of Enterococcus spp. and identification of species}

Table 3 presents the results of the counts of Enterococcus spp. in the feces and colons.

The consumption of meat-based feed contributed to proliferation of the number of these bacteria. As expected, the ingestion of pure culture led to a rise in the number of fecal enterococci, between $T_{30}$ and $T_{60}$. In the soy yogurt group, there was no significant change in this bacterial genus in the same period, although this product had the same viable count of $E$. faecium as the pure culture suspension.

The counts of enterococci in the colon tissue were only carried out at $\mathrm{T}_{60}$ and, as observed in the feces, there was no significant difference between groups III and IV.

The colonies selected for their distinct morphologies on $\mathrm{KF}$ medium were biochemically identified by the API 20 Strep (Tables 4 and 5).

Table 3. Viable cell count (log cfu/g) of enterococci in the feces and colon of rats during the experimental period.

\begin{tabular}{ccccc}
\hline \multirow{2}{*}{ Group } & \multicolumn{3}{c}{ Feces } & Colon \\
\cline { 2 - 5 } & $\mathbf{T}_{\mathbf{0}}$ & $\mathbf{T}_{\mathbf{3 0}}$ & $\mathbf{T}_{\mathbf{6 0}}$ & $\mathbf{T}_{\mathbf{6 0}}$ \\
\hline I & $6.18 \pm 0.09^{\mathrm{aA}}$ & $5.75 \pm 0.22^{\mathrm{aA}}$ & $6.07 \pm 0.04^{\mathrm{aA}}$ & $4.18 \pm 0.49^{\mathrm{A}}$ \\
II & $6.36 \pm 0.06^{\mathrm{aA}}$ & $7.50 \pm 0.03^{\mathrm{bB}}$ & $7.02 \pm 0.08^{\mathrm{abAB}}$ & $4.39 \pm 0.37^{\mathrm{AB}}$ \\
III & $6.14 \pm 0.04^{\mathrm{aA}}$ & $7.93 \pm 0.06^{\mathrm{bB}}$ & $8.01 \pm 0.03^{\mathrm{bBC}}$ & $5.30 \pm 0.50^{\mathrm{B}}$ \\
IV & $5.97 \pm 0.04^{\mathrm{aA}}$ & $7.34 \pm 0.05^{\mathrm{bB}}$ & $8.33 \pm 0.00^{\mathrm{cC}}$ & $5.80 \pm 0.07^{\mathrm{B}}$ \\
\hline
\end{tabular}

Values (means \pm standard deviation) with different small letters on the same row for feces, or with different capital letters in the same column for feces or colon, are significantly different $(P<0.05)$;

Rat group diets: I = casein-based feed alone; II = beef-based feed alone; III = beef-based feed supplemented after $\mathrm{T}_{30}$ with soy yoghurt; IV = beef-based feed supplemented after $\mathrm{T}_{30}$ with cell suspension from pure culture; $\mathrm{T}_{0}=$ start of standard (casein-based) and experimental (beef-based) base diets; $\mathrm{T}_{30}=$ start of supplementation with products $(30$ days $) ; \mathrm{T}_{60}=$ end of experiment $(60$ days $) ; \mathrm{n}=10$ 
Table 4. Identification of colon species, with their respective counts, of the colonies with distinct morphologies on KF selective media at the end of the experiment $\left(\mathrm{T}_{60}\right)$.

\begin{tabular}{|c|c|c|}
\hline Group & \multicolumn{2}{|c|}{ Species of Enterococcus (cfu/g) } \\
\hline \multirow{2}{*}{ I } & E. faecium & $1.2 \times 10^{2}$ \\
\hline & E. faecalis & $2.4 \times 10^{4}$ \\
\hline II & E. faecalis & $3.3 \times 10^{4}$ \\
\hline III & E. faecium & $1.9 \times 10^{5}$ \\
\hline IV & E. faecium & $8.2 \times 10^{5}$ \\
\hline
\end{tabular}

fermented soy product; IV = beef-based feed supplemented after $\mathrm{T}_{30}$ with cell suspension from pure culture; $\mathrm{T}_{0}=$ start of standard (casein-based) and experimental (beef-based) base diets; $\mathrm{T}_{30}=$ start of supplementation with products $\left(30\right.$ days); $\mathrm{T}_{60}=$ end of experiment (60 days); $\mathrm{n}=10$

Table 5. Identification of fecal species, with their respective counts, of the colonies with distinct morphologies on KF selective media at the start $\left(\mathrm{T}_{0}\right)$, day $30\left(\mathrm{~T}_{30}\right)$ and day $60\left(\mathrm{~T}_{60}\right)$ of the experimental period.

\begin{tabular}{|c|c|c|c|c|}
\hline \multirow{2}{*}{ Group } & \multicolumn{4}{|c|}{ Species of Enterococcus $(\mathrm{cfu} / \mathrm{g})$} \\
\hline & $\mathbf{T}_{\mathbf{0}}$ & $\mathbf{T}_{30}$ & & $\mathbf{T}_{60}$ \\
\hline \multirow{2}{*}{ I } & E. faecalis $1.5 \times 10^{6}$ & E. faecalis $4.3 \times 10^{5}$ & E. faecalis & $1.1 \times 10^{6}$ \\
\hline & & & E. avium & $1.6 \times 10^{4}$ \\
\hline \multirow[t]{2}{*}{ II } & E. faecalis $2.4 \times 10^{6}$ & E. faecalis $3.0 \times 10^{7}$ & E. faecalis & $1.1 \times 10^{7}$ \\
\hline & & E. avium $5.5 \times 10^{5}$ & & \\
\hline \multirow[t]{2}{*}{ III } & E. faecalis $1.4 \times 10^{6}$ & E. faecalis $7.9 \times 10^{7}$ & E. faecalis & $8.4 \times 10^{7}$ \\
\hline & & E. avium $\quad 1.4 \times 10^{6}$ & E. faecium & $1.6 \times 10^{7}$ \\
\hline \multirow[t]{2}{*}{ IV } & E. faecalis $9.2 \times 10^{5}$ & E. faecalis $1.7 \times 10^{7}$ & E. faecalis & $2.2 \times 10^{8}$ \\
\hline & & E. avium $2.9 \times 10^{6}$ & E. faecium & $5.5 \times 10^{6}$ \\
\hline
\end{tabular}

According to Table 4, E. faecium was found in the washed colons of groups I, III and IV at $\mathrm{T}_{60}$. Nevertheless, the rats of group I showed lower numbers of E. faecium $\left(10^{2} \mathrm{cfu} / \mathrm{g}\right)$ than the animals of groups III and IV $\left(10^{5} \mathrm{cfu} / \mathrm{g}\right)$.

At $\mathrm{T}_{60}, 100 \%$ of the enterococci present in the colon tissue of animals of groups III and IV belonged to E. faecium. However, the rats of group II did not show E. faecium in the colon, $100 \%$ of the enterococci being E. faecalis.

Regarding Table 5, at the beginning of the experimental period $\left(\mathrm{T}_{0}\right), 100 \%$ of Enterococcus species in the feces were $E$. faecalis. After 30 days $\left(\mathrm{T}_{30}\right)$ of consumption of formulated feed, there were changes in the fecal microbiota. The rats that received meat-based feed (II, III and IV) showed the species $E$. faecalis and E. avium. Group I continued to exhibit E. faecalis in the feces, but this species was found at a lower number than at $\mathrm{T}_{0}$.

The fecal microbiota of groups III and IV was altered again at $\mathrm{T}_{60}$ and the rats that consumed E. faecium in soy yogurt showed a higher count of this species $\left(10^{7} \mathrm{cfu} / \mathrm{g}\right)$ than the rats that received pure culture $\left(10^{6} \mathrm{cfu} / \mathrm{g}\right)$.

In general, the results indicate that the consumption of soy yogurt and pure culture of E. faecium CRL 183 did not increase the total population of enterococci in the colon of rats, but did change the pattern of species. One hundred percent of the enterococcal colonies isolated from the colon of groups III and IV were identified as E. faecium. 
It is important to point out that the colons of rats were removed and washed with sterile saline solution before the microbiological analysis. Therefore, the absence of E. faecalis and E. avium in the colon could have been due to the methodology applied.

On the other hand, Bejuk et al. (5) analysed 153 strains of Enterococcus isolated from human feces and observed that $90 \%$ were E. faecalis. The results of biochemical tests in our study showed that the composition of fecal enterococci was altered. At the beginning of the experiment, only E. faecalis was found, while after the consumption of meat-based feed the species present were E. faecalis and E. avium and, finally, after the ingestion of fermented soy product and pure culture, the species found in the rat feces were E. faecalis and E. faecium. It is worth mentioning that the age of animals can also interfere with the intestinal microbiota. Some studies have indicated a change in intestinal microbiota over time $(15,32)$.

Genomic DNA obtained from the colonies identified as $E$. faecium by API 20 Strep was used to amplify the $16 \mathrm{~S}-23 \mathrm{~S}$ rRNA spacer region. Figures 2 and 3 show the PCR products obtained from colonies isolated from colon and feces, respectively, on the $60^{\text {th }}$ day of the experimental period. It can be seen that the colonies isolated from the colon and feces of groups III and IV were confirmed as E. faecium.

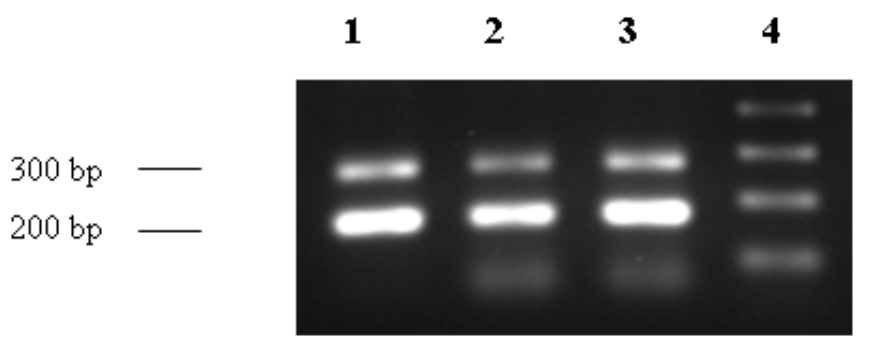

Figure 2. Agarose gel electrophoresis of PCR products obtained from colonies isolated from rat colon. Lane 1: $E$. faecium from group IV (beef-based feed supplemented after $\mathrm{T}_{30}$ with cell suspension from pure culture); Lane 2: E. faecium from group III (beef-based feed supplemented after $\mathrm{T}_{30}$ with fermented soy product); Lane 3: E. faecium CRL 183; Lane 4: 100-bp ladder.

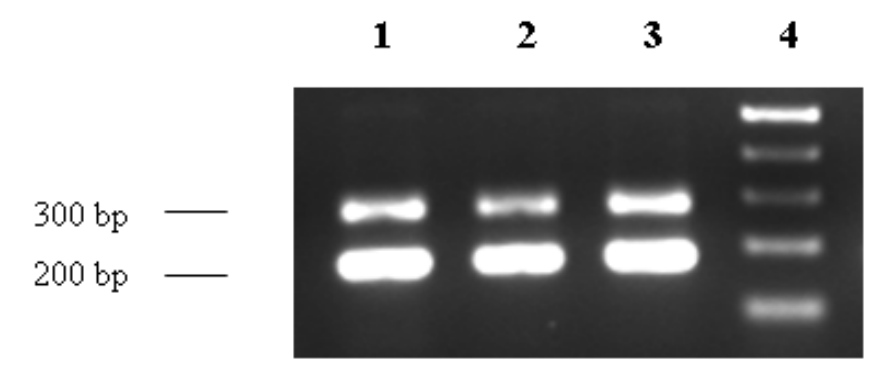

Figure 3. Agarose gel electrophoresis of PCR products obtained from colonies isolated from rat feces sampled at day 60 of the experimental period. Lane 1: E. faecium from group IV (beef-based feed supplemented after $\mathrm{T}_{30}$ with cell suspension from pure culture); Lane 2: E. faecium from group III (beef-based feed supplemented after $\mathrm{T}_{30}$ with fermented soy product); Lane 3: E. faecium CRL 183; Lane 4: 100-bp ladder.

The Ent 1 and Ent 2 primer combination generated two amplification products: one of $200 \mathrm{bp}$ and one of $300 \mathrm{bp}$. A second strain (CRL 39) was introduced into the present study to find out what size pattern would be generated with the same primer combination.

Figure 4 shows the DNA fragments amplified from the genomic DNA of E. faecium CRL 39 and detected on the same gel. There are two bands, at $300 \mathrm{bp}$ and $400 \mathrm{bp}$. This band pattern is different from that produced by strain CRL 183 (200 and $300 \mathrm{bp}$ ). These results indicate that E. faecium isolated from the colon and feces may be strain CRL 183.

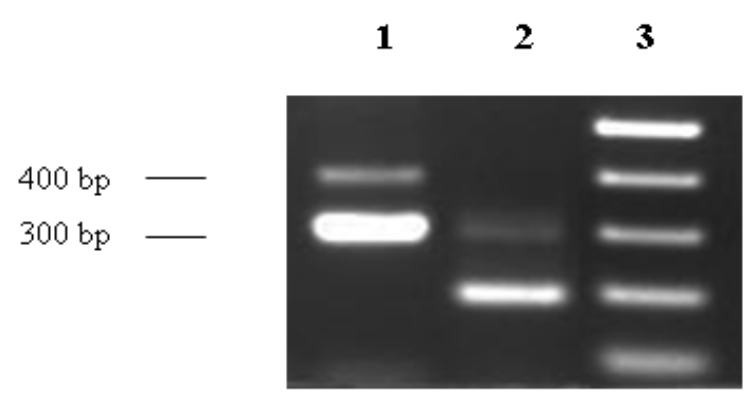

Figure 4. Agarose gel electrophoresis of PCR products obtained from E. faecium strains by using Ent 1 and Ent 2 primers. Lane 1: E. faecium CRL 39; Lane 2: E. faecium CRL 183; Lane 3: 100-bp ladder. 
The presence of E. faecium was confirmed by molecular methods (PCR) and it can be seen that only animals that received soy yogurt or pure culture showed E. faecium, in both feces and colon.

Survival during gastrointestinal transit is desirable in a probiotic microorganism for it to have a beneficial effect on the host (22). Our results show that E. faecium CRL 183 can survive the passage through the gastrointestinal tract and colonize the rat colon. However, further studies are required to verify the adhesion of this strain to the intestinal mucosa.

Our results suggest that the consumption of soy yogurt fermented with E. faecium CRL 183 and L. helveticus subsp. jugurti could change the species of Enterococcus spp. present in the feces and on the colon of rats fed on a beef-based diet. However, the fermented soy product and the pure culture of $E$. faecium CRL 183 also induced undesirable effects such as the increase of fecal $\mathrm{pH}$ and ammonia content in the feces of rats fed on the beef-based diet. Other studies are necessary to assess the influence of soy yogurt and E. faecium CRL 183 on the composition and metabolic activity of intestinal microbiota.

\section{ACKNOWLEDGEMENTS}

This study was supported by the Fundação de Amparo à Pesquisa do Estado de São Paulo and Programa de Apoio ao Desenvolvimento Científico da Faculdade de Ciências Farmacêuticas/UNESP. We are grateful to Roseli Ap. Pinto for help and technical assistance.

\section{REFERENCES}

1. Arroyo, G.; Peñas, E.; Pedrazuela, A.; Préstamo, G. (2005). Intestinal microbiota in rats fed with tofu (soy curd) treated under high pressure. Eur. Food Res. Technol. 60, 395-400.

2. Association of Official Analytical Chemists (2003). Official methods of analysis. 17.edn, 2. rev. Gaithersburg: AOAC.

3. Augenlicht, L.H.; Mariadason, J.M.; Wilson, A.; Arango, D.; Yang, W.; Heerdt, B.G.; Velcich, A. (2002). Short chain fatty acids and colon cancer. J. Nutr. 132, 3804S-3808S.
4. Bedani, R.; Rossi, E.A; Lepera, J.S.; Wang, C.C.; Valdez, G.F. (2006). Efeito do consumo de um novo produto fermentado de soja enriquecido com isoflavonas e cálcio sobre o tecido ósseo de ratas. Arch. Latin. Nutr. 56,146-152.

5. Bejuk, D.; Begovac, J.; Gamberger, D.; Tepes, N.K. (2000). Evaluation of phenotypic characteristics for differentiation of enterococcal species using an example based algorithm. Diagn. Microbiol. Infect. Dis. 38, 201-205.

6. Benno, Y.; Mitsuoka, T. (1992). Impact of Bifidobacterium on human fecal microflora. Microbiol. Immunol. 36, 683-694.

7. Bouhnik, Y.; Flourie, B.; D’Agay-Abensour, L.; Porchat, P.; Gramet, G.; Durand, M.; Rambaud, J.C. (1997). Administration of transgalactooligosaccharides increases fecal bifidobacteria and modifies colonic fermentation metabolism in healthy humans. J. Nutr. 127, 444-448.

8. Campbell, J.M.; Fahey, G.C.; Wolf, B.W. (1997). Selected indigestible oligosaccharides affect large bowel mass, cecal and fecal short-chain fatty acids, $\mathrm{pH}$ and microflora in rats. J. Nutr. 127, 30- 36.

9. Cavallini, D.C.U.; Bedani, R.; Bomdespacho, L.Q.; Vendramini, R.C.; Rossi, E.A. (2009). Effects of probiotic bacteria, isoflavones and simvastatin on lipid profile and atherosclerosis in cholesterol-fed rabbits: a randomized double-blind study. Lipids Health Dis. Doi: 10.1186/1476$511 \mathrm{X}-8-1$

10. Franz, C.M.A.P.; Stiles, M.E.; Scheleifer, K.H.; Holzapfel, W.H. (2003). Enterococci in foods - a conundrum for food safety. Int. J. Food Microbiol. 88, 105-122.

11. Gorbach, S.L.; Goldin, B.R. (1990). The intestinal microflora and the colon cancer connection. Rev. Infect. Dis. 12, 252-261.

12. Guarner, F.; Malagelada, J.R. (2003). Gut flora in health and disease. Lancet 361, 512-519.

13. Gudiel-Urbano, M.; Goñi, I. (2002). Effect of edible seaweeds (Undaria pinnatifida and Porphyra ternera) on the metabolic activities of intestinal microflora in rats. Nutr. Res. 22, 323-331.

14. Guiemonde, M.; Salminen, S. (2006). New methods for selecting and evaluating probiotics. Dig. Liver Dis. 38:S242-S247.

15. Hopkins, M.J.; Sharp, R.; Macfarlane, G.T. (2002). Variation in human intestinal microbiota with age. Dig. Liver Dis. 34, S12-S20.

16. Hosoda, M.; Hashimoto, H.; He, D.; Morita, H.; Hosono, A. (1996). Effects of administration of milk fermented with Lactobacillus acidophilus LA-2 on fecal mutagenicity and microflora in the human intestine. J. Dairy Sci. 79, 745-749.

17. Ichikawa, H.; Sakata, T.M. (1998). Stimulation of epithelial cell proliferation of isolated distal colon of rats by continuous colonic infusion of ammonia or short-chain fatty acids is nonadditive. J. Nutr. $128,843-847$.

18. Kim, K.I.; Lee, W.S.; Benevenga, N.J. (1998). Feedings diets containing high levels of milk products or cellulose decrease urease activity and ammonia production in rat intestine. J. Nutr. 128, 1186-1191. 
19. Kinouchi, F.L. (2006). "Iogurte" de soja como coadjuvante no tratamento de cancer de mama. Araraquara, Brasil, 85p. (PhD. Thesis. Faculdade de Ciências Farmacêuticas. UNESP).

20. Langa, S.; Fernández, A.; Martín, R.; Reviriego, C.; Marin, M.L.; Fernández, L.; Rodríguez, J.M. (2003). Differentiation of Enterococcus faecium from Lactobacillus delbruecckii subsp. bulgaricus and Streptococcus thermophilus strains by PCR and dot-blot hybridization. Int. J. Food Microbiol. 88, 197-200.

21. Ling, W.H.; Korpela, R.; Mykkänen, H.; Salminen, S.; Hänninen, O. (1994). Lactobacillus strain GG supplementation decreases colonic hydrolytic and reductive enzyme activities in healthy female adults. $J$. Nutr. 124, 18-23.

22. Lund, B.; Adamson, I.; Edlund, C. (2002). Gastrointestinal transit survival of an Enterococcus faecium probiotic strain administered with or without vancomycin. Int. J. Food Microbiol. 77, 109-115.

23. Macgarr, S.E.; Ridlon, J.M.; Hylemon, P.B. (2005). Diet, anaerobic bacterial metabolism, and colon cancer: a review of the literature. J. Clin. Gastroenterol. 39, 98-109.

24. Manzoni, M.S.J.; Rossi, E.A.; Carlos, I.Z.; Vendramini, R.C.; Duarte, A.C.G.O.; Tenorio, N.M.; Amorim, D.B.A.; Damaso, A.R. (2008) Fermented soy product supplemented with isoflavones affects adipose tissue in a regional-specific manner and improves HDL-cholesterol in rats fed on a cholesterol-enriched diet. Eur. Food Res. Technol. 227, 1591-1597.

25. Modler, G.M.; Mckellar, R.C.; Yaguchi, M. (1990). Bifidobacteria and bifidogenic factors. Can. Inst. Food Sci. Technol. J. 23, 29-41.

26. Moreno, M.R.F.; Sarantinopoulos, P.; Tsakalidou, E.; Vuyst, L.D. (2006). The role and application of enterococci in food and health. Int. J. Food Microbiol. 106, 1-24.

27. Reeves, P.G.; Nielsen, F.H.; Fahey, G. (1993). AIN-93 purified diets for laboratory rodents: final report of American Institute of Nutrition ad hoc writing committee on the reformulation of the AIN-76 rodent diet. $J$. Nutr. 123, 1939-1951.

28. Rossi, E.A.; Cavallini, D.C.U.; Carlos, I.Z.; Vendramini, R.C.; Dâmaso, A.R.; Valdez, G.F. (2008). Intake of isoflavone-supplemented soy yogurt fermented with Enterococcus faecium lowers serum total cholesterol and non-HDL cholesterol of hypercholesterolemic rats. Eur. Food Res. Technol. 228, 275-282.

29. Rossi, E.A.; Vendramini, R.C; Carlos, I.Z.; Oliveira, M.G.; Valdez, G.F. (2003). Efeito de um novo produto fermentado de soja sobre os lípides séricos de homens adultos normocolesterolêmicos. Arch. Latin. Nutr. 53, 47-51.

30. Rossi, E.A.; Vendramini, R.C.; Carlos, I.Z.; Pei, Y.C.; Valdez, G.F. (1999). Development of a novel fermented soymilk product with potencial probiotic properties. Eur. Food Res. Technol. 209, 305-307.

31. Rossi, E.A.; Vendramini, R.C.; Carlos, I.Z.; Ueiji, I.S.; Squinzari, M.M.; Silva Junior, S.I.; Valdez, G.F. (2000). Effects of a novel soy product on the serum lipids of hypercholesterolemic rabbits. Arq. Bras. Cardiol. 74, 213-216.

32. Saunier, K.; Doré, J. (2002). Gastrointestinal tract and the elderly: functional foods, gut microflora and healthy ageing. Dig. Liver Dis. 34, S19-S24.

33. Shiguemoto, G.E.; Rossi, E.A.; Baldissera, V.; Gouveia, C.H.; Valdez, G.M.F.; Perez, S.E.A. (2007). Isoflavone-supplemented fermented soy product associated with resistive physical exercise increase bone mineral density of ovariectomized rats. Mauritas 57, 261-270.

34. Simonová, M.; Lauková, A.; Styriak, I. (2005). Enterococci from rabbits - potential feed additive. Czech. J. Animal. Scie. 50, 416-421.

35. Sivieri, K.; Spinardi-Barbisan, A.L.T.; Barbisan, L.F.; Bedani, R.; Pauly, N.D.; Carlos, I.Z.; Benzatti, R.C.; Vendramini, R.C.; Rossi, E.A. (2008). Probiotic Enterococcus faecium CRL183 inhibit chemically induced colon cancer in male Wistar rats. Eur. Food Res. Technol. 228, 231-237.

36. Toit, M.; Franz, C.M.A.P.; Dicks, L.M.T.; Schillinger, U.; Haberer, P.; Warlies, B.; Ahrens, F.; Holzapfel, W.H. (1998). Characterization and selection of probiotic lactobacilli for a preliminary minipig feeding trial and their effect on serum cholesterol levels, faeces $\mathrm{pH}$ and faeces moisture content. Int. J. Food Microbiol. 40, 93-104.

37. Tsuiji, M.; Kawano, S.; Tsuji, S.; Nagano, K.; Ito, T.; Hayashi, N.; Fusamoto, H.; Kamada, T.; Tamura, K. (1992). Ammonia: a possible promoter in Helicobacter pylori related gastric carcinogenesis. Cancer Lett. 65, 15-18.

38. Vendramini, A.P. (2002). Efeito da ingestão de um produto de soja fermentado com Enterococcus faecium $e$ Lactobacillus helveticus na produção de citocinas, óxido nítrico e peróxido de nitrogênio. Araraquara, Brasil, 96p (PhD. Thesis. Faculdade de Ciências Farmacêuticas, UNESP).

39. Wollowski, I.; Rechkemmer, G.; Pool-Zobel, B. (2001). Protective role of probiotics and prebiotics in colon cancer. Am. J. Clin. Nutr. 73, 451S$455 \mathrm{~S}$. 